\title{
ПРАВОВЕ РЕГУЛЮВАННЯ ЗАБЕЗПЕЧЕННЯ СЛІДЧИМ СУДДЕЮ ФУНКЦІЙ СУДОВОГО КОНТРОЛЮ В ЗАКОНОДАВСТВІ ОКРЕМИХ ЗАРУБІЖНИХ КРАЇН
}

Журавель О. 0.

У статmі проведено ретроспективний аналіз положень національного Кримінального процесуального законодавства, міжнародно-правових актів, законодавства окремих зарубіжних країн щодо забезпечення конституційних гарантій прав, свобод і законних інтересів особи та реалізації функцій судового контролю слідчим суддею на стадії досудового розслідування із цих та інших питань, на підставі яких окремо розглядаються питання щодо становлення, розвитку та вирішення проблем у даному напрямі з урахуванням різних історичних етапів. здійснено порівняльне дослідження забезпечення даного правового інституту в національному кримінальному процесі та окремих галузей права та кримінального процесу в зарубіжних країнах, практики Європейського суду із прав людини з урахуванням змін в економіці, політиці та в суспільних відносинах.

Ключові слова: слідчий суддя, генезис, правовий інститут, кримінальний процес, доктрина, правові проблеми, стадія, слідчий, прокурор, кримінальне провадження, учасники.

В статье осуществлен ретроспективный анализ положений национального Уголовного процессуального законодательства, международно-правовых актов, законодательства отдельных зарубежных стран по обеспечению конституционных гарантий прав, свобод и законных интересов личности, а также реализации функций судебного контроля следственным судьей на стадии досудебного расследования по этим и другим вопросам, на основании чего отдельно рассматриваются вопросы относительно становления, развития и решения проблем в данном направлении с учетом различных исторических этапов. Осуществлено сравнительное исследование обеспечения этого правового института в национальном уголовном процессе и в отдельных отраслях права и уголовного процесса в зарубежных странах, практики Европейского суда по правам человека с учетом изменений в экономике, политике и в общественных отношениях.

Ключевые слова: следственный судья, генезис, правовой институт, уголовный процесс, доктрина, правовые проблемы, стадия, следователь, прокурор, уголовное производство, участники.

The author of the article provided a retrospective analysis of the provisions of the national criminal procedural legislation, international legal acts, legislation of certain foreign countries regarding the provision of constitutional guarantees of the rights, freedoms and legitimate interests of a person and the exercise of judicial control by an investigating judge at the stage of pretrial investigation on these and other issues. The author considered some issues of formation, development and resolution of problems of the court control, taking into account different historical stages. A comparative study of the provision of this legal institute in the national criminal process and of certain branches of law and criminal procedure in foreign countries and the practice of the European Court of Human Rights has been carried out taking into account changes in the economy, politics and public relations. On the basis of the indicated and available scientific positions of some scientists and scientific schools, a discussion on improving the performance of functions by an investigating judge in matters of judicial control concerning the observance of the rights, freedoms and legal interests of all participants in criminal proceedings, appealing the actions or inaction of officials conducting and supervise the conduct of a proper pre-trial investigation on the basis of which the author's scientific position in this area has been provided.

The general conclusion is drawn that there are prospects for scientific research in this area, since in recent years scientific publications of this direction have been carried out in insufficient number, despite the adoption of new international legal acts and improvement of criminal procedural legislation in some foreign countries, expansion the case law of the European Court of Human Rights on the exercise of judicial review functions and the reform of pre-trial investigation bodies in the National Police of Ukraine, prosecutors' office and national courts.

Key words: investigating judge, genesis, law institute, criminal process, doctrine, legal problems, stage, investigator, prosecutor, criminal proceedings, participants.

Постановка проблеми та їі актуальність. Встановлено, що національне законодавство вдосконалює напрями посилення захисту прав, свобод і законних інтересів громадян, зокрема тих, що опинились у сфері кримінальних процесуальних правовідносин. При цьому значна увага приділяється розширенню повноважень судових інстанцій, зокрема на досудових стадіях кримінального процесу, що постійно закріплюється в законодавчих актах. Новелою чинного КПК України стало введення такого учасника кримінального процесу, як слідчий суддя. У зв'язку із вказаним слідчий суддя серед інших учасників кримінального провадження заслуговує на значну і особливу увагу та потребує свого окремого наукового дослідження, оскільки надані йому недосконалі повноваження у правозастосовній діяльності сьогодні ефективно не виконуються. Це підтверджують і постійні, але не завжди доречні зміни його повноважень, зокрема про закріплення а потім відміну призначення ним у досудовому розслідуванні судових експертиз та ін. Звертає на себе увагу деяка невизначеність меж повноважень слідчого судді, оскільки у кримінальному процесуальному законодавстві відстуня чітка їх регламентація і процесуальна повнота, не враховано кореляцію його функцій як слідчого судді, його обов'язків за основним місцем діяльності судді як такого та ін. Вказане спонукає до дискусії та потребує напрацювання певних пропозицій і рекомендацій щодо вдосконалення положень чинного КПК України та іншого законодавства. Вивчення досвіду і законодав- 
ства окремих зарубіжних країн із цих питань надасть можливість використання їх у процесі вдосконалення національного законодавства.

Стан дослідження. Поява у чинному КПК України такого учасника кримінального судочинства, як слідчий суддя, не стало новиною, оскільки він згідно з генезисом існував у кримінальному судочинстві ще з 1864 року в царській Росії, на території якої існувала й теперішня Україна. Водночас функціонування такого суб'єкта у кримінальному процесі на будь-яких історичних етапах і сьогодні викликало постійні дискусії з огляду на доктринальну несумісність досудового розслідування і самого судового розгляду конкретного кримінального правопорушення однією й тією ж судовою інстанцією. У результаті вказаного та інших історичних обставин генезису такий правовий інститут не прижився в окремих губерніях Росії. Сьогодні правовий інститут слідчого судді пройшов відповідну процесуальну трансформацію, яка викликає певну зацікавленість із точки зору наукових і прикладних досліджень, що й спонукало до обрання теми цієї статті. Питання сучасного інституту слідчого судді знайшли своє відображення в наукових працях таких учених, як: В.Г. Дрозд. Ю.І. Крючко, Л.М. Москвич, І.В. Назарова, Р.Р. Трагнюк, В.О. Кряжкова, Л.О. Сергієнко, П.М. Рабіновича, Л.М. Москвич, М.А. Макарова, В.О. Попелюшко А.В. Пономаренко, 0.О. Юхна та інших вчених. На рівні кандидатських дисертацій ці питання досліджувались Бондюком А.Ф. (2017 р.), Полюховичем О.І. (2017 р.) та ін. вченими. Ураховуючи, що після прийняття у 2012 році чинного КПК України до нього внесено понад 580 змін і доповнень, а також внесення змін у 2018 і 2019 роках до Конституції України і законодавства, що регулює діяльність і повноваження судових інстанцій, зокрема й доповнень, а потім і скасування певних повноважень слідчого судді, які також сьогодні $є$ недосконалими, - вказане потребує свого переосмислення та подальшого концептуального наукового і прикладного дослідження.

Метою і завданням дослідження $\epsilon$ з'ясування і порівняльний аналіз окремих питань правового регулювання забезпечення функцій судового контролю з боку слідчого судді в міжнародно-правових актах в окремих зарубіжних країнах та національному законодавстві з метою його вдосконалення в цьому напрямі.

Виклад основного матеріалу. Досліджуючи підняте питання, слід підтримати наукову позицію К.Ф. Гуценка, Л.В. Головка, Б.А. Филимонова про те, що слідчий суддя в Україні $\epsilon$ певним «інструментом» суспільної довіри до суду, якому доручено реалізацію конституційних гарантій поваги до захисту прав людини у кримінальному судочинстві. Діяльність слідчого судді має лише одну мету - це об'єктивне дослідження всіх обставин справи. Його головним завданням $\epsilon$ забезпечення суду якісним матеріалом проведеного дослідження, вірогідність якого під час розгляду не викликала би сумнівів [1, с. 110]. Слід дослідити дану новелу чинного КПК України з урахуванням історичного досвіду, законодавства окремих зарубіжних країн та міжнародно-правових актів із метою визначення напрямів iї подальшого вдосконалення. Виходячи з дослідження генезису історичної появи та становлення слідчого судді у світі встановлено, що такий суб'єкт уперше 3'явився в законодавстві та правозастосовній діяльності Франції ще у 1810 році на підставі прийнятого відомого «наполеонівського» Кодексу кримінального розслідування 1808 року. Цей кодекс застосовувався як базовий більше півтора століття, без значних змін, створивши для Європи концептуально нову систему проведення слідства, основним і незалежним суб'єктом якого став слідчий суддя. Пізніше цей процесуальний інститут був застосований країнами романо-германської правової системи Західної Європи: Австрією, Бельгією, Іспанією, Італією, Нідерландами, Францією, Німеччиною, Швейцарією. У країнах класичного правового порядку відносно слідчого судді сформувались різні підходи. Так, у Бельгії, Нідерландах і Франції слідчі судді представляють органи попереднього слідства першої інстанції [1, с. 6-12]. В Австрії, Нідерландах і Франції слідчі судді представляють органи попереднього слідства першої інстанції [2, с. 351]. За останні роки такий учасник кримінального провадження з'явився у кримінальному процесуальному законодавстві Латвії, Литви, Молдови, Казахстану, України.

В Австрії, Німеччині дільничий (слідчий) суддя виконує функції судді дізнавача, який проводить слідчі дії та безпосердньо бере участь у виявленні, оформленні та оцінці доказів. При цьому слідчі судді використовують до підозрюваного, обвинуваченого заходи державного примусу [2, с. 351]. Таким чином, згідно із законодавством окремих зарубіжних країн слідчий суддя не приймає справу до свого провадження і вирішує ті питання, що пов'язані із забезпеченням досудового розслідування. За результатами дослідження їхніх повноважень встановлено, що слідчі судді беруть участь у процесі доказування, застосовують процесуальні заходи примусу до підозрюваного, обвинуваченого, запобігають конфліктам між сторонами обвинувачення. Певну зацікавленність представляє такий досліджуваний процесуальний учасник у законодавстві Німеччини, де він представлений дільничним суддею, який виконує функції судді-дізнавача, в головне завдання якого входить забезпечення легитимності окремих доказів у справі, та він виступає суб'єктом окремих заходів державного примусу [3, с. 75]. Зокрема, згідно з параграфом 165 КПК ФРН він наділений повноваженнями в невідкладних випадках виконувати доцільні слідчі дії без погодження клопотання із прокурором у разі неможливості встановлення контакту з ним, але із встановленням допустимості наявних обставин для цього. Крім вказаного, згідно з параграфом 114 цього ж кодексу він повинен проводити судові процесуальні дії під час видання наказу про арешт особи. В окремих земельних і судових інстанціях та судах мають місце певні особливості в роботі слідчих суддей [4, с. 131-137].

В Австрійському кримінальному процесуальному законодавстві після 2008 року суттєво змінились повноваження слідчого судді. Так, сьогодні він має право вирішувати питання щодо тримання особи під вартою на стадіїі досудового розслідування та давати згоду на такі слідчі дії, як: обшук та оперативне спостереження [5]. Практика цієї країни дає перевагу прокурорському нагляду, оскільки його система не передбачає отримання дозволу на підставі клопотання від слідчого судді. Наприклад, поліція має право здійснити арешт підозрюваного до 48 годин, але в разі необхідності продовження цього терміну лише прокурор може звертатись до слідчого судді з таким клопотанням. У свою чергу, слідчий суддя тільки на підставі особистого спілку- 
вання з підозрюваним, зокрема й у місцях утримання чи арештанських домах, може вирішувати таке питання, але за присутності сторін кримінального процесу, коли обговорюються підстави висунення підозри та арешту і тримання під вартою [5]. У кримінальному процесуальному законодастві Італії посада слідчого судді (спеціалізованого слідчого судді), який закріплений за досудовим розслідуванням, $\epsilon$ в кожному трибуналі, судах адміністративного чи муніципального округу. Слідчий суддя здійснює судовий контроль за попереднім розлідуванням, зокрема за діяльністю працівників прокуратури та поліції та дотриманням із їхнього боку прав підслідних: санкціонування арешту, прослуховування телефоних переговорів, дотримання термінів розслідування, а в окремих випадках - протоколювання показань важливих свідків. Вказані положення було б доцільно запровадити і в законодавстві України.

В Іспанії слідчі судді входять у суддівський корпус на рівних правах з іншими суддями, зокрема під час розслідування тяжких і особливо тяжких злочинів, що в подальшому передаються у провінційні суди. Слідчі судді за своєю функцією $є$ слідчими, але не можуть розглядати розслідувані ними справи. Вони можуть розглядати дрібні правопорушення і переглядати рішення світових судей. При цьому вони здійснюють судовий контроль за застосуванням заходів процесуального примусу та розгляд скарг на дії і рішення органів попереднього розслідування [6]. Система слідчих суддів в Іспаніє $є$ двустепеневою. Наприклад, у Мадриді діють декілька центральних слідчих судів, що поширюють свої повноваження на всю територію цієї країни та виконують повноваження щодо підсудності національним (федеральним) судам. Існують ще й провінціальні суди, що поєднують також функції слідчих суддів, зокрема під час вирішення таких питань, як: застосування запобіжних заходів, розгляд скарг на дії і рішення посадових осіб у справах, що підсудні судам першої інстанції. Рішення цих судів можуть бути оскарженими у провінціальних судах. Слідчі суди Іспанії (в тому числі центральні) не $\epsilon$ незалежними та самостійними органами судового контролю за попереднім розслідуванням, тому що входять у загальну систему судів і мають однаковий правовий статус поряд з іншими судами країни. Ми підтримуємо наукову позицію тих вчених (М.М. Ковтун, Т.С. Бухранова та ін.), які зазначають, що недоцільно запозичати досвід Іспанії щодо поділу одного і того ж судового органу на слідчі та юрисдикційцні функції.

Правозастосовна діяльність Нідерландів характеризується високим рівнем довіри до діяльності слідчих судів, які вповноважені виконувати подвійну роль у кримінальному провадженні. 3 одного боку, ці суди захищають права підозрюваного i обвинуваченого, а з іншого, мають право надавати дозвіл на проведення обшуку житла з метою виявлення наркотиків, зброї, а також для оперативних заходів, пов'язаних із встановленням засобів прослуховування. При цьому слідчий суддя здійснює безпосередній нагляд за досудовим розслідуванням. Цю функцію в України виконує процесуальний керівник досудового розслідування (прокуратура), тобто він стежить за законністю на цій стадії кримінального процесу [7, с. 100]. Такі повноваження слідчих суддів доцільно було б закріпити і в Україні, оскільки в нас процесуальний керівник представляє орган, що в подальшому буде підтримувати обвинува- чення в суді, що не відповідає доктринальним постулатам теорії права та кримінального процесу зокрема.

Якщо дослідити запровадження слідчого судді у країнах пострадянського простору, то в більшості з них такий суб'єкт вже запроваджений, а в деяких таке питання ще розглядається. Так, ст. 40 КПК Латвії закріплює положення про процесуальний статус и функції слідчого судді. У доповнення до повноважень слідчого судді національного КПК України: в КПК Латвії до його повноважень ще додатково належить і сприяння ознайомленню особи, яка має право на захист, із матеріалами спеціальних слідчих дій, які не долучаються до кримінального провадження (початковими документами), та невиправдане порушення у кримінальному процесі охоронюваних законом таємниць. Крім цього, такий суддя не може здійснювати паралельно функції судового контролю як слідчий суддя, з поєднанням функцій судді першої інстанції та ін. У ст. 54 КПК Казахстану слідчого суддю закріплено з першого січня 2015 року (із внесенням змін від 31 жовтня того ж року), він визнається суддею першої інстанції, в його повноваження входить судовий контроль за дотриманням прав, свобод і законних інтересів осіб у кримінальному судочинстві. Зокрема, за вказаними змінами він має право санкціонувати проведення огляду, обшуку, виїмки, особистого обшуку, застосовувати запобіжні заходи та ін.

Законодавство Молдови закріплює слідчого суддю із кримінального переслідування, який $\epsilon$ гарантом дотримання прав особи під час досудового розслідування і судового контролю за заходами, що застосовуються під час такого переслідування. Окремої уваги заслуговують його повноваження (ст. 31 КПК) щодо скерування кримінального провадження, розгляд клопотань прокурора щодо проведення слідчих дій, негласних слідчих дій та заходів забезпечення кримінального провадження (ч. 1 ст. 30 КПК), розгляд скарг на дії органів досудового розслідування та прокуратури (ч. ч. 2 і 3 ст. 300 КПК), виконання функій, що притаманні органам слідства (ст. 109, 110 КПК), а також здійснення окремих функцій відносно виконання вироків судів (ст.ст. 469-471). Слід підтримати наукову позицію М.М. Ковтуна и Т.С. Бухранова про те, що в Молдові до компетенції слідчого судді із кримінального переслідування входить здійснення майже всіх превентивних судово-контрольних дій [8, с. 32-36], що ми підтримуємо. Дослідження міжнародно-правових актів та рішень Європейського суду із прав людини свідчать про те, що завдяки ним в Україні введено як новелу правовий інститут слідчого судді, що суттєво вплинуло на значне покращення судового контролю саме на стадії досудового розслідування. У своєму рішенні по справі Ратушна проти Україн від 02 грудня 2010 року ЄСПЛ підтверджує вищезазначений нами висновок.

Висновки. Системи судового контролю поєднують в одному судовому органі як слідчі, так і юрисдикційні функції, що свідчить про неможливість цього поєднання в системі держав континентальної системи права, оскільки слідчий суддя не може бути одночасно ефективним суб'єктом досудового розслідування і неупередженим учасником контролю за дотриманням законності та обгрунтованим носієм своїх ухвал. Найбільш оптимальною моделлю $є$ та, в якій слідчий суддя виконує свої обов'язки автономно від судових інстанцій, що покликані до розгляду та вирішення кри- 
мінального провадження по суті. Відповідно до міжнародно-правових актів слідчий суддя представляє суддівську владу, до повноважень якої входить здійснення контролю за досудовим розслідуванням; дії посадових осіб мають правообмежувальний характер, при цьому дотримуються відповідні гарантії захисту прав, свобод і законних інтересів особи у кримінальному процесі. На підставі вищезазначеного слід акцентувати увагу на важливості дослідження доказової бази під час дотримання засади ріноправності сторін кримінального провадження, з урахуванням можливості сторони захисту подавати власні докази та обов'язкового ознайомлення з фактами і позицією, що надається стороною обвинувачення. Положення кримінального процесуального законодавства окремих зарубіжних країн, на які акцентовано у статті, доцільно запровадити в національному законодавстві, з урахуванням їх критичної оцінки автором. Утім, підняті питання не $\epsilon$ остаточними і підлягають окремому дослідженню або науковому вивченню.

\section{Література}

1. Гуценко К.Ф., Головко А.В., Филимонов Б.А. Уголовный процесс западных государств : учеб. пособие. Москва. Зерцало. 2001. С. 334.
2. Барабаш А.С. Прокурор - следственный судья. Уголовная юстиция : связь времен : избранные материалы Междунар. научн. конф. (г. Санкт-Петербург 6-8 окт. 2010 г.) Москва. Актион-Медиа. 2012. С. 6-12.

3. Головко В.Л. Дознание и предварительное следствие в уголовном процессе Франции. Москва : СПАРТАК. 1995. С. $75-76$.

4. Болгова В.В. Основи публічного права. Самара. 2009. $351 \mathrm{C}$

5. Law commission. Reforming the law. URL : http://www.lawcom (дата звернення: 29.01. 2020).

6. Судебная система Испании. URL: http: / /kommentarii. org/strani mira eciklopediy/ispanty.html.

7. Герасименко С.Г. Судовий контроль на досудових стадіях кримінального судочинства : національне законодавство та зарубіжний досвід : дис. ...канд. юрид. наук : 12.00.09. Запоріжжя. 2012. С. 100-101.

8. Ковтун Н.Н., Бурханова Т.С. Институт судебного следователя и специализированого следственного судьи в контексте опыта стран континентальной системы права. Российский следователь. 2001. № 17. С. 32-36.

Журавель О. О., acniparm Харківського національного університету внутрішніх справ 